\title{
Correlation between Aspects of Academic Motivation among Adolescents in Rural Areas
}

\author{
Reena* and Bimla Dhanda
}

Department of Human Development and Family Studies, I. C. College of Home Sciences, CCSHAU, Hisar - 125004, Haryana, India

*Corresponding author

\section{A B S T R A C T}

\section{Keywords}

Academic motivation, Extrinsic motivation identified, Extrinsic motivation- introjected, Extrinsic motivation - externa regulation, Amotivation and adolescents

Article Info

Accepted: 12 April 2018 Available Online: 10 May 2018
The present study was carried out on 300 adolescents from Panipat district of Haryana state. Academic motivation Scale by Areepattamannil (2006) was used to assess the relationship between aspects of academic motivation of adolescents. The scale included four dimensions namely; extrinsic motivation -identified, extrinsic motivation- introjected, extrinsic motivation - external regulation and amotivation. Results revealed that extrinsic motivation -identified were correlated with extrinsic motivation -introjected $\left(\mathrm{r}=0.68^{* *}\right)$, and extrinsic motivation -external regulation $\left(\mathrm{r}=0.57^{* *}\right)$. Extrinsic motivation -external regulation were correlated extrinsic motivation -identified extrinsic motivation introjected $\left(\mathrm{r}=0.68^{* *}\right)$. Amotivation were correlated with extrinsic motivation introjected $\left(\mathrm{r}=0.76^{* *}\right)$.

\section{Introduction}

Adolescents need academic motivation that occurs during the transitions to middle school and high school age (Skinner et al., 2008). Motivation has been defined as the attribute that "moves" us to do or not do something. Academic motivation is multidimensional in nature, and is comprised of three global types of motivation: intrinsic motivation, extrinsic motivation, and amotivation (Deci and Ryan, 2000). Lepper et al., (2005) postulate that intrinsic and extrinsic motivation may be largely orthogonal dimensions of motivation in school, and developing both intrinsic and extrinsic motives can be adaptive for students.
Within-domain interrelations among these motivation constructs were generally consistent with previous research. More important, consistent patterns of relations were observed in four different academic domains within each age group (Bong, M., 2001). Teacher support has been associated with greater school/academic engagement and motivation, as well as better academic performance Demaray and Malecki (2006).

Academic motivation is considered a prerequisite for success in academic settings. It can be considered as extended personintrinsic motivation which arises from an interaction within the person. Achievement 
motivation is "a pattern of planning of actions and of feelings connected with striving to achieve some internalized standard of excellence, as contrasted for example, will power or friendship. Academic motivation and social intelligence level of adolescents, dependency of academic motivation on social intelligence and most interesting by the indicators of the academic motivation and social intelligence.

\section{Materials and Methods}

\section{Participant}

A sample of 300 hundred students studying in the age group of 13-14 years and studying in the $8^{\text {th }}$ grade. These adolescents were selected from six government schools from three Block of district Panipat. The boys and girls were included in the sample.

\section{Instrument}

Academic motivation Scale by Areepattamannil (2006) was used to assess the relationship between aspects of academic motivation of adolescents.

\section{Statistical analysis}

Descriptive analysis and Correlation coefficient was used to analysis the results.

\section{Procedure}

Present study was conducted purposively at rural government schools of the district Panipat of state Haryana. Random sampling procedure was used to select the sample. A sample of 300 hundred students studying in the age group of 13-14 years and studying in the $8^{\text {th }}$ grade. These adolescents were selected from six government schools from three Block of district Panipat. The boys and girls were included in the sample. Academic motivation
Scale by Areepattamannil (2006) was used to assess the relationship between aspects of academic motivation of adolescents

\section{Results and Discussion}

\section{Correlation between aspects of academic motivation}

It was found that extrinsic motivation identified were correlated with extrinsic motivation -introjected $(\mathrm{r}=0.68 * *)$ and extrinsic motivation -external regulation $\left(\mathrm{r}=0.57^{* *}\right)($ Table 1$)$.

Results supported by Sikhwari (2004) who observed that intrinsic motivation seems to be the most desirable form of motivation, and extrinsic motivation also proved to be important in some educational settings.

Extrinsic motivation -external regulation were correlated extrinsic motivation -identified extrinsic motivation - introjected $(r=0.68 * *)$. Extrinsic motivation - external regulation were correlated with extrinsic motivation identified. Chowdhury et al., (2007) viewed that motivation is inner drive that directs students' behavior towards the fulfillment of their goal. Result revealed that extrinsic and intrinsic motivation has positive relationship with academic motivation.

Another aspects amotivation were correlated with extrinsic motivation -introjected $(\mathrm{r}=$ $\left.0.76^{* *}\right)$. Amotivation is undesirable and not conducive to academic motivation at all. Rodriguez (2009) agreed the intrinsic motivational properties linked to the academic self-concept as students with positive academic self-concepts are more likely to be intrinsically motivated and more likely to achieve academically. Results revealed that aspects of academic motivation were significantly positively correlated. 
Table.1 Correlation between aspects of academic motivation of adolescents

\begin{tabular}{|c|c|c|c|c|c|}
\hline \multirow{2}{*}{$\begin{array}{l}\text { Sr. } \\
\text { No. }\end{array}$} & \multirow{2}{*}{$\begin{array}{l}\text { Aspects of } \\
\text { Academic } \\
\text { motivation }\end{array}$} & \multicolumn{4}{|c|}{ Aspects of Academic motivation } \\
\hline & & $\begin{array}{c}\text { Extrinsic } \\
\text { motivation - } \\
\text { identified }\end{array}$ & $\begin{array}{c}\text { Extrinsic } \\
\text { motivation - } \\
\text { introjected }\end{array}$ & $\begin{array}{l}\text { Extrinsic motivation } \\
\text {-external regulation }\end{array}$ & Amotivation \\
\hline 1. & $\begin{array}{l}\text { Extrinsic } \\
\text { motivation - } \\
\text { identified }\end{array}$ & 1.00 & - & - & - \\
\hline 2. & $\begin{array}{l}\text { Extrinsic } \\
\text { motivation - } \\
\text { introjected }\end{array}$ & $0.68 * *$ & 1.00 & & - \\
\hline 3. & $\begin{array}{l}\text { Extrinsic } \\
\text { motivation - } \\
\text { external } \\
\text { regulation }\end{array}$ & $0.57 * *$ & $0.68 * *$ & 1.00 & - \\
\hline 4. & Amotivation & 0.09 & $0.76^{*}$ & 0.05 & 1.00 \\
\hline
\end{tabular}

Ahmed and Bruinsma (2006) found that academic motivation was positively related to academic achievement. Also found that the positive relationship between academic selfconcept and intrinsic motivation significant. Therefore, those the students felt positive about themselves and their academic abilities were more intrinsically motivated for academic tasks.

\section{Finding}

All aspects of academic motivation and were significantly correlated with each other except a motivation respectively.

\section{References}

Ahmed, W., and Bruinsma, M. (2006). A structural model of self-concept, autonomous motivation and academic performance in cross-cultural perspective. Electronic Journal of Research in Educational Psychology 10(4) 551-572.
Bong, M. (2001). Between and within domain relations of academic motivation among middle and high school students: selfefficacy, task value and achievement goals. Journal of Educational Psychology, 93(1), 23-29

Chowdhury, Mohammed S. and Shahabuddin (2007). Self-efficacy, motivation and their relationship to academic performance of Bangladesh College Students.

Deci, E.L., and R.M. Ryan. (2000). The 'what' and 'why' of goal pursuits: Human needs and the self-determination of behaviour. Psychological Inquiry. 4: 227-268.

Demary M.K and Malecki, C.K (2006). Relation between sources of perceived sports and maladjustment for student at risk. Pschology in the School 39(3), 305-316

Lepper, M.R., Corpus, J.H. and Iyengar, S.S. (2005). Intrinsic and extrinsic motivational orientations in the classroom: Age differences and 
academic correlates. Journal of Educational Psychology, 97(2) 184196.

Rodriguez, C. (2009). The impact of academic self-concept, expectation and the choice of learning strategy on academic achievement: the case of business students. Higher Education Research and Development, 28(5) 523539.
Sikhwari, T.D. (2004). The relationship between affective factors and the academic achievement of students at the University of Venda. Unpublished MEd- dissertation. Pretoria: Unisa.

Skinner, E. A., Furrer, C., Marchand, G., and Kindermann, T. (2008). Engagement and disaffection in the classroom: Part of a larger motivational dynamic? Journal of Educational Psychology, 100: 765-781.

\section{How to cite this article:}

Reena and Bimla Dhanda. 2018. Correlation between Aspects of Academic Motivation among Adolescents in Rural Areas. Int.J.Curr.Microbiol.App.Sci. 7(05): 1639-1642.

doi: https://doi.org/10.20546/ijcmas.2018.705.193 